\title{
Politics in Africa
}

\section{SECOND EDITION}

Dennis Austin

Dennis Austin has thoroughly revised his excellent text to take full account of recent events and scholarship. "Should be read by anyone seeking to understand a continent that has moved so quickly from nationalist euphoria to postindependence malaise" - Journal of Politics. "Would make an excellent introduction to modern African politics in an undergraduate African history course" - History Teacher. A University of Rhode Island book. Paper, \$8.95 (\$10.75 export)

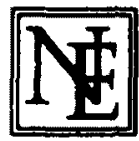

\section{UNIVERSITY PRESS} OF NEW ENGLAND

\section{African Studies}

Founded as Bantu Studies in 1921, the Journal represents 62 years of uninterrupted publication.

Volume 42, 1983 includes, among others, the following papers:

The structure and function of the song in the Tsonga folktale. Mary C. Bill Land and politics in Lesotho. JA.G. Perry

Utban bus boycott in Alexandra Township, 1957. G.H. Pirie

The elusive unity of Sir George Grey's library: Robert Thornton

Opting out of Coloured rule: the Brown voortrekkers of South Africa and their constitution. Peter Carstens

Population movement around the northern Kalahari. George T. Nurse Annual subscriptions: (Individuals) R10 (Institutions) R20 Plus GST (South Africa) or R1 bank exchange (elsewhere)

\section{African Studies is published by WITWATERSRAND UNIVERSITY PRESS 1 Jan Smuts Avenue 2001 Johannesburg, South Africa}




\section{CAIFIIEIRS D'IÉTUUIDIES AAFICAANIES}

A Quarterly Journal of Man and Society in Africa

Special issue :

\section{African State Systems CEA 87-88, XXII-3-4}

Forty years after the epoch-making African Political Systems, the Cahiers d'Études africaines are devoting a special (double) issue to a collection of essays on pre-colonial African States.

These essays are not so much a theoretical reflexion on the origins of the State as a series of convergent pragmatic approaches bearing on such topics as the re-organization of kin groups and clan segments, and of social dependency, on the role of production relationships and exchange networks, on ideological structuration and the manipulation of popular knowledge, etc. Examples are taken from all over sub-Saharan Africa, from the Western Sahel to the Channel of Moçambique.

\section{With contributions from}

Ivor Wilks - Emmanuel Terray - Roger Botte • John K. Thornton Michael S. Bisson - Michel Izard - Robin Law - Marc H. Piault David S. Newbury - Claude-Hélène Perrot • David W. Cohen Pierre Bonte - Claudine Vidal

Editorial Office : EHESS, 54 boulevard Raspail, 75006 Paris Subscriptions and Sale : CID, I3I boulevard Saint-Michel, 75005 Paris

EDITIONS DE L'ÉCOLE DES HAUTES ETUDES

EN SCIENCES SOCIALES • PARIS 


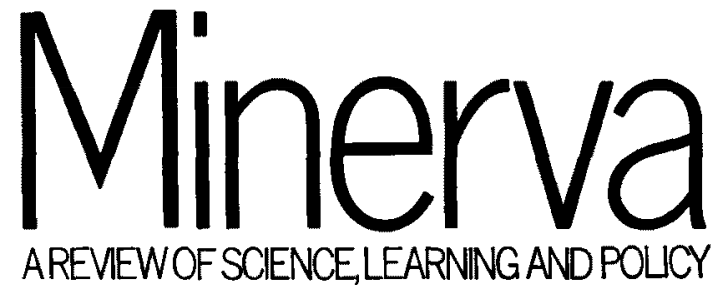

Editor: EDWARD SHILS

Minerva, now in its twentieth year, deals with the fundamental social, economic, political and administrative problems of higher education and scientific research in their contemporary relevance and in an historical perspective. Since its inception, Minerva has come to be regarded as the leading international journal in the field of higher educational and science policy.

In addition to four long articles in each issue, Minerva also reprints reports and documents which are otherwise difficult of access, as well as review articles on important books and editorial comments on pressing current problems.

\section{Contents of Volume XX Numbers 1-2 (Double issue)}

\section{ARTICLES}

British Higher Education, 1960-80: A Personal Retrospect Lord Annan

Preparation for the Advent: The Establishment of Sociology as a Discipline in

American Universities in the Late Nineteenth Century J.Graham Morgan American Foundations and the Support of Economic Research, 1913-29 David M. Grossman

Natural Knowledge in a Traditional Culture: Problems in the Study of the History of Chinese Science Yung Sik Kim

\section{REPORTS AND DOCUMENTS}

I The Obligations of University Teachers

I The Academic Ethic

II Dishonesty in the Academic Profession: Yale Policy Statement on Collaborative Research

II An Innovation in German Higher Education: The Private University

I The Private University: Its Possibilities and Limitations in the German Federal Republic Hans-Willi Nolden

II Do We Lack Pioneering Research? An Interview with Professor Klaus Weissermel

\section{BOOK REVIEWS}

Reviews by Arnold Thackray, Charles C. Gillispie, Kenneth Mellanby, A. G. Keller, Larissa Lomnitz, Alvin Weinberg

Annual subscription: $£ 18.00 / \$ 45.00$ Single copy $£ 5.00 / \$ 12.00$

Minerva, 59 St. Martin's Lane, London WC2N 4JS 


\title{
THE JOURNAL OF
}

\section{MODERN AFRICAN}

STUDIES

\section{VOLUME 2 I Nos I, 2, 3 \& 4}

\author{
EDITED BY \\ DAVID KIMBLE
}

CAMBRIDGE UNIVERSITY PRESS

(CAMBRIDGE)

LONDON NEW YORK NEW ROCHELLE

MELBOURNE SYDNEY

$19^{8} 3$ 


\section{PUBLISHED BY}

THE PRESS SYNDICATE OF THE UNIVERSITY OF CAMBRIDGE

The Pitt Building, Trumpington Street, Cambridge CB2 IR P

32 East $57^{\text {th }}$ Street, New York, NY 10022

to Stamford Road, Oakleigh, Melbourne 3166, Australia

(C) Cambridge University Press $198_{3}$

Printed in Great Britain at the University Press, Cambridge 


\section{THE JOURNAL OF MODERN AFRICAN STUDIES}

The Journal offers a quarterly survey of politics, economics, and related topics in contemporary Africa.

The main emphasis is upon the peoples and policies, the problems and progress of this dynamic and disparate continent; upon the many societies that are evolving rather than the essential characteristics of the old; upon the present, not on the more distant past. The best current work is sought from specialists in different academic disciplines, whose contributions can illuminate and crossfertilise one another.

The Journal seeks to promote a deeper understanding of what is happening in Africa today. It is intended for both the political scientist and the practical politician, the administrator and the advocate, the economist and the educator, the banker and the business man, the diplomat and the technocrat, the civil servant and the nationalist leader. All have something to contribute to these pages and, it is hoped, much to learn from them.

Editorial policy avoids commitment to any political viewpoint or ideology, whether imperialism, pan-Africanism, capitalism, socialism, or nationalism. Such concepts, however, have relevance to the modern African situation, and merit serious discussion, often from several different points of view, in order that controversial issues may be fairly examined.

(C) Cambridge University Press 1983

Contributors of accepted articles will be asked to assign their copyright, on certain conditions, to Cambridge University Press, to help protect their material, particularly in the U.S.A.

\section{Copying}

This journal is registered with the Copyright Clearance Center, 2 I Congress St., Salem, Mass. or970. Organisations in the U.S.A. who are also registered with C.C.C. may therefore copy material (beyond the limits permitted by sections 107 and 108 of U.S. copyright law) subject to payment to C.C.C. of the per copy fee of $\$ 05.00$. Code $0022-278 x / 83 / 2828-0001$ \$05.00. This consent does not extend to multiple copying for promotional or commercial purposes.

ISI Tear Service, 350 I Market Street, Philadelphia, Pennsylvania I9 104, U.S.A., is authorised to supply single copies of separate articles for private use only.

For all other use, permission should be sought from the Cambridge or New York offices of the Cambridge University Press. 


\section{CAMBRIDGE UNIVERSITY PRESS}

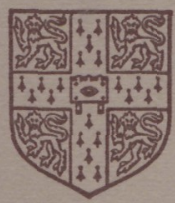

The Pitt Building, Trumpington Street,

Cambridge CB2 1RP

\section{East 57th Street,}

New York, N.Y. 10022

10 Stamford Road, Oakleigh,

Melbourne 3166, Australia

(c) Cambridge University Press 1983 